\title{
Smoking influences on the thickness of marginal gingival epithelium
}

\author{
Influências do fumo sobre a espessura do epitélio oral da \\ gengiva marginal
}

\author{
Cristina Cunha Villar* \\ Antonio Fernando Martorelli de Lima**
}

\begin{abstract}
Smoking patients show reduction of inflammatory clinical signs that might be associated with local vasoconstriction and an increased gingival epithelial thickness. The purpose of this work was to evaluate the thickness of the marginal gingival oral epithelium in smokers and non-smokers, with clinically healthy gingivae or with gingivitis. Twenty biopsies were obtained from four different groups. Group I: non-smokers with clinically healthy gingivae $(n=5)$. Group II: non-smokers with gingivitis $(n=5)$. Group III: smokers with clinically healthy gingivae $(n=5)$. Group IV: smokers with gingivitis $(n=5)$. These biopsies were histologically processed, serially sectioned at $5 \mu \mathrm{m}$, stained with H. E., and examined by image analysis software (KS400), which was used to perform the morphometric evaluation and the quantification of the major epithelial thickness, the epithelial base thickness and the external and internal epithelial perimeters. Differences between the four groups were analyzed using ANOVA test and Tukey's test. The criteria for statistical significance were accepted at the probability level $p<0.05$. A greater epithelial thickness was observed in smokers independent of the gingival health situation.
\end{abstract} DESCRIPTORS: Gingiva; Epithelium; Tobacco.

\begin{abstract}
RESUMO: Pacientes fumantes freqüentemente apresentam redução dos sinais clinicos inflamatórios da gengivite, associada, em grande parte, a vasoconstrição local e aumento da espessura epitelial. O objetivo deste trabalho foi avaliar a espessura do epitélio oral da gengiva marginal de pacientes fumantes e não fumantes, nos estados de saúde gengival e gengivite. Foram obtidos vinte fragmentos de tecido gengival de quatro grupos de pacientes. Grupo I: não fumantes com saúde gengival $(n=5)$. Grupo II: não fumantes com gengivite $(n=5)$. Grupo III: fumantes com saúde gengival $(n=5)$. Grupo IV: fumantes com gengivite $(n=5)$. As biópsias receberam processamento histológico de rotina, e os cortes semi-seriados com $5 \mu \mathrm{m}$ de espessura foram corados com H. E. Com auxílio do sistema de imagens KS400 foram quantificadas a espessura epitelial maior e a espessura da base epitelial e determinados os valores dos perimetros epiteliais externo e interno. Os dados foram avaliados pelo ANOVA e pelo teste de Tukey, considerando significativo o valor de $\alpha=0,05$. Os resultados mostraram valores da espessura da base epitelial maior $(p<0,05)$ nos pacientes fumantes, independentemente do estado de saúde gengival.
\end{abstract}

DESCRITORES: Gengiva; Epitélio; Tabaco.

\section{INTRODUCTION}

The association between tobacco smoking and periodontal health has been studied in several clinical and epidemiological investigations $\mathbf{s}^{1,2,3,4,5,7,8,12,13}$. Those studies suggest that by-products originated from tobacco oxidation modify the clinical characteristics and the progression of periodontal diseases, and described smoking habit as a risk factor for periodontal diseases ${ }^{7,8,13}$.

Some early studies indicated that smoking patients showed more intense inflammatory gingival signs than non-smoking ones ${ }^{13}$. This finding was generally interpreted as related to a less efficient oral hygiene and its consequent intense plaque accumulation in smokers. Conversely, high tobacco consumption seemed to reduce gingival bleeding ${ }^{2}$. Later studies confirmed the reduction of inflammatory signs in smokers, suggesting that smoking could modify the inflammatory response to dental plaque accumulation ${ }^{3,4,5,7}$.

The gingivitis experimental model in smoking and non-smoking patients showed that the plaque formation rate was similar in both groups ${ }^{3}$. However, smokers displayed a less pronounced gingival inflammatory reaction as compared with non-smokers. The reduction of clinical inflammatory signs ${ }^{1,2,3,5,7}$ is confirmed by the decrease in gingival bleeding and suppuration on probing ${ }^{1,3,5,7}$, tissue redness, edema ${ }^{1,3,5}$, and the amount of blood vessels in the marginal gingival tissue ${ }^{3}$. 
Villar CC, Lima AFM de. Smoking influences on the thickness of marginal gingival epithelium. Pesqui Odontol Bras $2003 ; 17(1): 41-5$.

The reduction of clinical inflammatory signs in smokers, particularly regarding gingival bleeding upon probing and tissue redness, can be attributed to the cotinine ${ }^{5}$, a nicotine metabolic by-product, which has a peripheral constrictive action on gingival vessels. Although the literature indicates an increase in oral mucosa epithelium thickness in smokers ${ }^{6}$, there is no morphometric study assessing the oral gingival epithelial thickness in those patients.

The objective of this work was to investigate the relation between the thickness of the marginal gingival oral epithelium in smokers and non-smokers, with clinically healthy gingivae or with gingivitis.

\section{MATERIALS AND METHODS}

\section{Study population}

Twenty young adult patients (20 to 35 years old) were selected, with clinical signs of gingival health (grade 0, Löe \& Silness gingival index, 1964) or gingivitis (grade 2 , Löe \& Silness gingival index), and a clinical indication for periodontal surgery (crown lengthening or apically positioned flap) at one intraoral site per patient. Among the patients, 10 were smokers and 10 non-smokers (Table 1). Individuals that had smoked an average of 10 or more cigarettes per day for at least 5 years were considered smokers.

Former smokers, pregnant women, patients with periodontal pocket or bone loss identified by clinical exam with a second generation periodontal electronic probe (Florida Probe ${ }^{\circledR *}$ system) or by digital radiographic images, obtained by the image system Acu-Ray ${ }^{\circledR * *}$, individuals with systemic and/or immunologic abnormalities, detected in physical or laboratorial exams, or those who had used any drug on the 4 weeks before the experiment were excluded from the sample.

\section{Tissue preparation and morphometric analysis}

All marginal gingival biopsies $(0.4 \mathrm{~cm}$ by $0.2 \mathrm{~cm})$ from different parts of the oral cavity were obtained during periodontal surgery as part of a routine periodontal treatment independent of this study. Only one biopsy was taken per patient. The intra-buccal antisepsis was performed using chlorhexidine $0.2 \%$, and the extra-buccal antisepsis was carried out with a povidone-iodine solution. The anesthetic technique was performed on the surgical site location, avoiding any local anesthetic infiltration.

The marginal gingival biopsies were divided into four groups, according to the donor's gingival health and smoking habit. Group I $(\mathrm{n}=5)$ : non-smokers with clinically healthy gingivae; Group II ( $\mathrm{n}=5)$ : non-smokers with gingivitis; Group III $(\mathrm{n}=5)$ : smokers with clinically healthy gingivae; Group IV ( $n=5)$ : smokers with gingivitis.

The study was submitted to and approved by the Ethics Committee in Research, School of Dentistry of Piracicaba, State University of Campinas (UNICAMP), under the protocol \# 076/2001, subjected to the 196/96 resolution of the Brazilian National Health Council (10/10/96). All patients

TABLE 1 - Patient clinical information.

\begin{tabular}{|c|c|c|c|c|}
\hline Group & Patient & Age & Gender & Location \\
\hline \multirow{5}{*}{ I } & 1 & 32 & M & 13 palatal \\
\hline & 2 & 23 & $\mathrm{~F}$ & 36 buccal \\
\hline & 3 & 26 & F & 26 palatal \\
\hline & 4 & 22 & $\mathrm{~F}$ & 26 palatal \\
\hline & 5 & 26 & $\mathrm{~F}$ & 25 palatal \\
\hline \multirow{5}{*}{ II } & 1 & 29 & M & 25 palatal \\
\hline & 2 & 22 & $\mathrm{~F}$ & 14 palatal \\
\hline & 3 & 20 & $\mathrm{~F}$ & 37 lingual \\
\hline & 4 & 32 & $\mathrm{~F}$ & 26 palatal \\
\hline & 5 & 35 & F & 26 palatal \\
\hline \multirow{5}{*}{ III } & 1 & 35 & M & 44 buccal \\
\hline & 2 & 28 & $\mathrm{~F}$ & 16 palatal \\
\hline & 3 & 27 & M & 25 palatal \\
\hline & 4 & 32 & M & 26 palatal \\
\hline & 5 & 21 & $\mathrm{~F}$ & 16 palatal \\
\hline \multirow{5}{*}{ IV } & 1 & 30 & M & 25 palatal \\
\hline & 2 & 35 & $\mathrm{~F}$ & 25 palatal \\
\hline & 3 & 34 & $\mathrm{~F}$ & 46 lingual \\
\hline & 4 & 22 & F & 16 palatal \\
\hline & 5 & 28 & $\mathrm{~F}$ & 17 palatal \\
\hline
\end{tabular}

$\mathrm{M}=$ male $; \mathrm{F}=$ female; $\mathrm{I}=$ non-smokers with clinically healthy gingivae; II = non-smokers with gingivitis; III $=$ smokers with clinically healthy gingivae; $\mathrm{IV}=$ smokers with gingivitis . 
Villar CC, Lima AFM de. Smoking influences on the thickness of marginal gingival epithelium. Pesqui Odontol Bras 2003;17(1):41-5.

gave a written informed consent for all phases of the research.

The samples were immediately fixed in 10\%

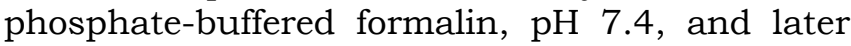
embedded in paraffin and serially sectioned at $5 \mu \mathrm{m}$. The samples were cut at right angles to the oral vestibular epithelium, resulting in a section exhibiting both sulcular and oral epithelium. The slides were stained with hematoxylin and eosin $(\mathrm{H}$. E.) and were observed in a light microscope at $10 \mathrm{X}$ (objective) magnification equipped with a video camera. The images generated by the video were transferred to a microcomputer with image analysis software ${ }^{* * *}$, which was also used to perform the morphometric analysis. Under a blind protocol the slides were number coded and subsequently all the analyses were carried out by the same investigator. The morphometric analysis was performed considering the oral epithelium.

The external (EEP) and internal (IEP) epithelial perimeters, the major epithelial thickness $(\mathrm{MET}=$ distance between the external epithelial surface and the epithelial crista tip) and the epithelial base thickness $(\mathrm{EBT}=$ distance between the external epithelial surface and basal membrane located between two cristae) were evaluated. EEP and IEP were evaluated in duplicate in three different fields per slide. MET and EBT were evaluated in 5 different areas in each of the three different fields, totaling 15 measures per slide. The final data for each parameter represent the mean for the quantification in the analyzed fields.

\section{Statistics analysis}

The morphometric results were expressed as arithmetic mean \pm standard deviation for each group. The data showed homogeneity and the differences between the four groups were analyzed using the ANOVA test (ANOVA - Tukey's multiple comparison test). The criterion for statistical significance was accepted at the probability level $\mathrm{p}<0.05$. The difference in cigarette consumption between Groups III and IV was analyzed using the Student's $t$-test. The criterion for statistical significance was accepted at the probability level $\mathrm{p}<0.05$.

\section{RESULTS}

Smokers with clinically healthy gingivae (Group III) had consumed an average of $17 \pm 8.37$ cigarettes per day during $9.8 \pm 3.49$ years, while smokers with gingivitis (Group IV) had consumed
$15 \pm 3.54$ cigarettes per day during $8.8 \pm 2.39$ years, without any significant statistical difference between both groups $(p=0.15)$ (Table 2).

The marginal gingival epithelium was classified as keratinized stratified squamous epithelium with small intercellular spaces. The spinous stratum occupied about $50 \%$ of the total epithelial thickness and the stratum corneum was more exuberant in smoking patient samples (Figure 1). The presence of glycogen in the keratinocytes was observed in some samples of both Group II and Group IV.

There was no statistical significant difference in MET between smokers and non-smokers, regardless of the clinical gingival condition. However, EBT was larger in smoking patients. $(p<0.05)($ Tables 3 and 4)

There was no significant statistical difference in both EEP and IEP between smoker and non-smoker patients, regardless of the clinical gingival condition (Tables 5 and 6).

\section{DISCUSSION}

The inflammatory response induced by dental plaque accumulation can be modified by tobacco by-products ${ }^{5}$, such as cotinine, a by-product of nicotine that has a peripheral vasoconstriction action that reduces gingival clinical signs of bleeding, redness, and edema ${ }^{3,5}$.

The increase in local temperature and the by-products from tobacco oxidation induce an increase in the oral mucosa and in the oral gingival epithelial thickness ${ }^{6}$. The epithelium of such mucosae is stratified and keratinized; however, the buccal and labial epithelial mucosae do not present pronounced projections. The epithelial architecture is determined by location and functional demand ${ }^{14}$.

TABLE 2 - Smoking habits characteristics.

\begin{tabular}{l|c|c|c}
\hline \hline \multirow{2}{*}{ Habit } & \multicolumn{2}{|c|}{ Group } & \multirow{2}{*}{ p value } \\
\cline { 2 - 3 } & III $(\mathrm{n}=5)$ & IV $(\mathrm{n}=5)$ & \\
\hline $\begin{array}{l}\text { Diary } \\
\text { consumption }\end{array}$ & $17 \pm 8.37$ & $15 \pm 3.54$ & 0.59 \\
\hline $\begin{array}{l}\text { Habit duration } \\
\text { years })\end{array}$ & $9.8 \pm 3.49$ & $8.8 \pm 2.39$ & 0.27 \\
$\begin{array}{l}\text { Total } \\
\text { exposition }\end{array}$ & $173 \pm 83.72$ & $146 \pm 55.50$ & 0.15 \\
\hline $\begin{array}{l}\text { III }=\text { smokers with clinically healthy gingivae; } \\
\text { IV }=\text { smokers with gingivitis. Student's } t \text {-test }(\mathrm{p}<0.05) .\end{array}$
\end{tabular}

*** Kontron ${ }^{\circledR}$ S 400 - Kontron Elektronik, München, Germany. 
Villar CC, Lima AFM de. Smoking influences on the thickness of marginal gingival epithelium. Pesqui Odontol Bras 2003;17(1):41-5.

In the samples evaluated throughout this study, the spinous stratum occupied about $50 \%$ of the total epithelium thickness and the keratinocytes were apart by small intercellular spaces. In the smokers' samples, the stratum corneum was more pronounced (Figure 1). These events were similar to the ones already described in the literature ${ }^{6}$.

Presence of material similar to glycogen was noted in some samples from clinical inflamed areas (Figure 2). The inflammation can interfere in the epithelial maturation process and in the original conformation of tonofilaments, compromising the complete keratinization ${ }^{10}$. These authors verified the presence of a glycogen-like material inside the epithelium cells, indicating a disturbance in the cellular differentiation process.

The morphometric analysis showed an increase in the MET in clinically healthy gingival samples when compared to inflamed samples, in both smok-

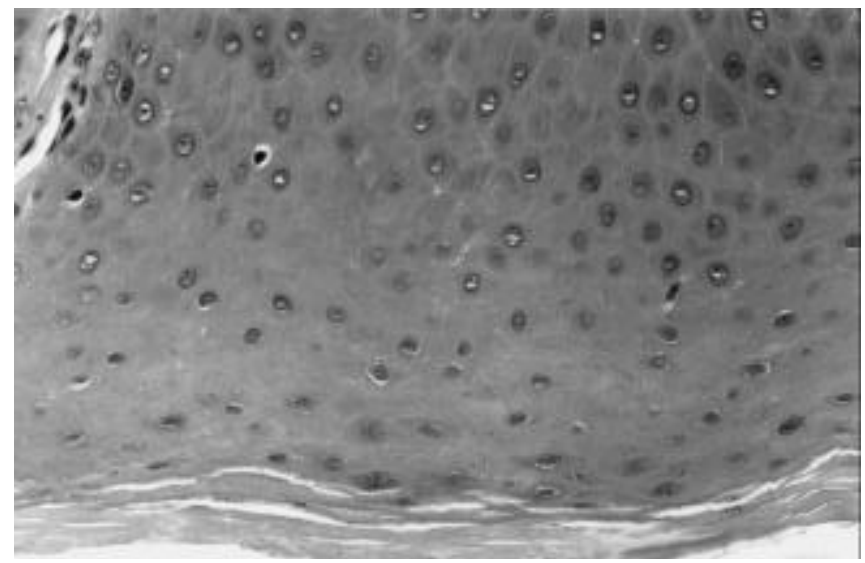

FIGURE 1 - Exuberant stratum corneum presence in oral gingival epithelium in a smoking patient (H. E., $40 \mathrm{X}$ ).

TABLE 3 - Mean \pm standard deviation of major epithelial thickness (MET) in non-smokers (NS) and smokers (S), with clinically healthy gingivae $(\mathrm{H})$ and gingivitis $(\mathrm{G})$. Values expressed in $\mu \mathrm{m}$.

\begin{tabular}{c|c|c}
\hline \hline \multirow{2}{*}{$\begin{array}{c}\text { Clinical } \\
\text { condition }\end{array}$} & \multicolumn{2}{|c}{ Smoking habit } \\
\cline { 2 - 3 } & NS $(\mathrm{n}=10)$ & $\mathrm{S}(\mathrm{n}=10)$ \\
\hline $\mathrm{H}(\mathrm{n}=10)$ & $460.86 \pm 38.26 \mathrm{Aa}$ & $534.38 \pm 54.61 \mathrm{Aa}$ \\
\hline $\mathrm{G}(\mathrm{n}=10)$ & $434.77 \pm 53.84 \mathrm{Aa}$ & $506.05 \pm 84.61 \mathrm{Aa}$ \\
\hline \hline
\end{tabular}

ANOVA $(p<0.05)$. In the rows, means followed by the same capital letter are not different. In the columns, means followed by the same lowercase letter are not different. ing and non-smoking patients, but this difference did not achieve statistical significance (Table 3). The gingival inflammation reduces the epithelial thickness and can potentially cause clinical ulceration ${ }^{9,11}$.

In our samples, we found an increase in the gingival EBT in smoking patients (Table 4). The results in Tables 5 and 6 show that there was no significant statistical difference $(p>0.05)$ in both EEP and IEP, regardless of the clinical condition. However, IEP was larger in gingivitis' cases. The epithelium is a non-vascular tissue that depends on the subjacent connective tissue. The inflammation causes connective tissue disorganization, modifying the blood availability and impeding the elimination of metabolites from the epithelium. Epithelium projections are more frequent and protuberant during gingival inflammation ${ }^{9}$.

Our results suggest that among all the negative consequences of tobacco on the periodontium, the tobacco influence on signs and symptoms of

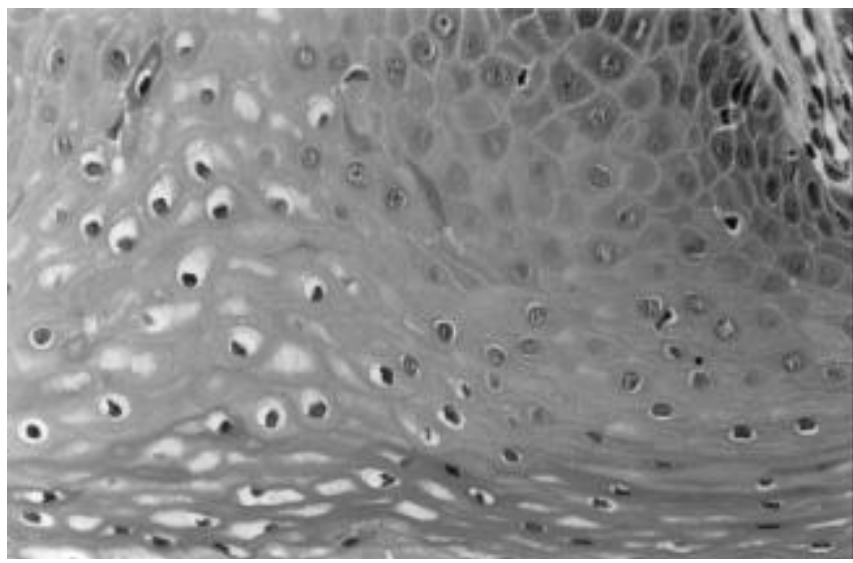

FIGURE 2 - Keratinization process disturbance and glycogen-like cytoplasmic accumulation noted in the gingival pocket epithelium in a sample from a clinical inflamed area (H. E., $10 \mathrm{X})$.

TABLE 4 - Mean \pm and standard deviation of epithelial base thickness (EBT) in non-smokers (NS) and smokers $(\mathrm{S})$, with clinically healthy gingivae $(\mathrm{H})$ and gingivitis $(\mathrm{G})$. Values expressed in $\mu \mathrm{m}$.

\begin{tabular}{c|c|c}
\hline \hline \multirow{2}{*}{$\begin{array}{c}\text { Clinical } \\
\text { condition }\end{array}$} & \multicolumn{2}{|c}{ Smoking habit } \\
\cline { 2 - 3 } & $\mathrm{NS}(\mathrm{n}=10)$ & $\mathrm{S}(\mathrm{n}=10)$ \\
\hline $\mathrm{H}(\mathrm{n}=10)$ & $250.91 \pm 37.58 \mathrm{Ba}$ & $259.88 \pm 59.22 \mathrm{Aa}$ \\
\hline $\mathrm{G}(\mathrm{n}=10)$ & $174.86 \pm 59.22 \mathrm{Ba}$ & $274.68 \pm 47.26 \mathrm{Aa}$ \\
\hline \hline
\end{tabular}

ANOVA $(p<0.05)$. In the rows, means followed by different capital letters are different. In the columns, means followed by different lowercase letters are different. 
Villar CC, Lima AFM de. Smoking influences on the thickness of marginal gingival epithelium. Pesqui Odontol Bras $2003 ; 17(1): 41-5$.

TABLE 5 - Mean \pm standard deviation of external epithelial perimeter (EEP) in non-smokers (NS) and smokers $(\mathrm{S})$, with clinically healthy gingivae $(\mathrm{H})$ and gingivitis $(\mathrm{G})$. Values expressed in $\mu \mathrm{m}$.

\begin{tabular}{l|c|c}
\hline \hline \multirow{2}{*}{$\begin{array}{c}\text { Clinical } \\
\text { condition }\end{array}$} & \multicolumn{2}{|c}{ Smoking habit } \\
\cline { 2 - 3 } & NS $(n=10)$ & $S(n=10)$ \\
\hline$H(n=10)$ & $647.84 \pm 26.71 \mathrm{Aa}$ & $634.41 \pm 3.52 \mathrm{Aa}$ \\
\hline $\mathrm{G}(\mathrm{n}=10)$ & $643.10 \pm 8.71 \mathrm{Aa}$ & $655.86 \pm 26.17 \mathrm{Aa}$ \\
\hline \hline
\end{tabular}

ANOVA $(\mathrm{p}<0.05)$. In the rows, means followed by different capital letters are different. In the columns, means followed by different lowercase letters are different.

are more frequent and protuberant during gingival inflammation'.

Our results suggest that among all the negative consequences of tobacco on the periodontium, the tobacco influence on signs and symptoms of gingival inflammation induced by plaque accumulation must be considered. Although the exact mechanism of its influence is still unclear, smoking must be considered a high risk factor for chronic periodontal disease.

\section{CONCLUSION}

Regardless of the health condition, smoking patients showed increased epithelial base and

\section{REFERENCES}

1. Bergström J. Oral hygiene compliance and gingivitis expression in cigarette smokers. Scand J Dent Res 1990;98:497-503.

2. Bergström J, Floderus-Myrhed B. Co-twin control study of the relationship between smoking and some periodontal disease factors. Community Dent Oral Epidemiol 1983; 11:113-6.

3. Bergström J, Preber H. The influence of cigarette smoking on the development of experimental gingivitis. J Periodontal Res 1986;21:668-76.

4. Bergström J, Preber H. Tobacco use as a risk factor. J Periodontol 1994;65:545-50.

5. Bergström J, Persson L, Preber H. Influence of cigarette smoking on vascular reaction during experimental gingivitis. Scand J Dent Res 1988;96:34-9.

6. Daniels TE, Chou L, Greenspan JS, Grady DG, Hauck WW, Greene JC, et al. Reduction of Langerhans cells in smokeless tobacco-associated oral mucosal lesions. J Oral Pathol Med 1992;21:100-4.

7. Danielsen B, Manji F, Nagelkerke N, Fejerskov O, Baelum V. Effect of cigarette smoking on the transition dynamics in experimental gingivitis. J Clin Periodontol 1990;17:159-64.
TABLE 6 - Mean \pm standard deviation of internal epithelial perimeter (IEP) in non-smokers (NS) and smokers $(\mathrm{S})$, with clinically healthy gingivae $(\mathrm{H})$ and gingivitis $(\mathrm{G})$. Values expressed in $\mu \mathrm{m}$.

\begin{tabular}{l|c|c}
\hline \hline \multirow{2}{*}{$\begin{array}{c}\text { Clinical } \\
\text { condition }\end{array}$} & \multicolumn{2}{|c}{ Smoking habit } \\
\cline { 2 - 3 } & NS $(\mathrm{n}=10)$ & $\mathrm{S}(\mathrm{n}=10)$ \\
\hline $\mathrm{H}(\mathrm{n}=10)$ & $2257.46 \pm 326.86 \mathrm{Aa}$ & $2004.15 \pm 577.38 \mathrm{Aa}$ \\
\hline $\mathrm{G}(\mathrm{n}=10)$ & $2342.60 \pm 527.03 \mathrm{Aa}$ & $2537.00 \pm 712.40 \mathrm{Aa}$ \\
\hline \hline
\end{tabular}

ANOVA $(p<0.05)$. In the rows, means followed by the same capital letter are not different. In the columns, means followed by the same lowercase letter are not different.

stratum corneum thickness. The increased epithelial thickness can contribute to the reduction of inflammatory clinical signs in the gingival tissue.

\section{ACKNOWLEDGMENTS}

The authors are grateful to Oslei Paes de Almeida and Ana Cristina do Amaral Godoy (Pathology Area, Oral Diagnosis Department, School of Dentistry of Piracicaba, State University of Campinas) for their technical support, and to Glaucia Maria Bovi Ambrosano (School of Dentistry of Piracicaba, State University of Campinas) for her statistical assistance.

8. Haber J, Wattles J, Crowley M, Mandell R, Joshipura K, Kent RL. Evidence for cigarette smoking as a major risk factor for periodontitis. J Periodontol 1993;64:16-23.

9. Hara K, Takahashi T, Noara H, Kobayashi S. A correlation between microscopic numerical evaluation, clinical scoring and total collagen content in inflamed gingivae. J Periodontol 1975;46:459-64.

10. Katchburian E, Arana V. Histologia e Embriologia Oral. Texto - Atlas - Correlações clínicas. São Paulo: Panamericana, 1999.

11. Polson AM, Greenstein G, Caton J. Relationships between epithelium and connective tissue in inflamed gingiva. $\mathrm{J} \mathrm{Pe}-$ riodontol 1981;52:743-6.

12. Preber H, Bergström J. Cigarette smoking in patients referred for periodontal treatment. Scand J Dent Res 1986;94:102-8.

13. Preber H, Kant T, Bergström J. Cigarette smoking, oral hygiene and periodontal health in Swedish army conscripts. J Clin Periodontol 1980;7:106-13.

14. Ten Cate AR. Oral histology - development, structure and function. $5^{\text {th }}$ ed. St Louis: Mosby, 1998. 